UDC "004.773.7:811.111":377.36

Hanna M. Shalatska

$\mathrm{PhD}$ in Philological sciences, Associate Professor, Department of Foreign Languages

SIHE “Kryvyi Rih National University”, Kryvyi Rih, Ukraine

ORCID ID 0000-0002-1231-8847

shalatska@i.ua

\title{
THE EFFICIENCY OF MOOCS IMPLEMENTATION IN TEACHING ENGLISH FOR PROFESSIONAL PURPOSES
}

\begin{abstract}
The article considers the way of integrating Massive Open Online Courses (MOOCs) into the educational process and determining their role in students' motivation to learn a foreign language for professional purposes. The goal of the research is studying the efficiency of implementation of MOOCs as part of students' independent work while learning a foreign language for professional purposes at the university. Considering the increasing need for education around the world, the role of MOOCs will become more important than ever before. Consequently, engaging students whose major is Information Technology in learning the integrating course could enhance their skill and knowledge of programming. The integration of MOOCs in the process of learning English for professional purposes will help to personalize learning environments and prepare future professionals. Research shows that the successful implementation of MOOCs can bring new opportunities to learners, such as increasing English proficiency level, developing critical thinking, decision-making, problem-solving and time management. We consider the scientific problem connected with the efficiency of using Internet resources and MOOCs, ways of using interactive online technologies in the traditional educational process, potential and identified new opportunities offered by e-learning. Our observations are also related to the problem of integrating MOOCs into the curriculum; adapting them to the thematic modules and different subjects. Research shows that successful integration of MOOCs in the process of learning a foreign language for professional purposes depends on a number of factors. Each stage of our research has been carefully considered in the article. This study shows the efficiency of MOOCs as additional resources in studying English for professional purposes and describes the use of information and communication technology of distance learning in the traditional educational process. In this article, we describe how this idea is being realized and can be adopted by universities willing to use benefits of MOOCs in teaching English for professional purposes.
\end{abstract}

Keywords: MOOC; motivation; implementation; independent learning; flipped classroom; lifelong learning.

\section{INTRODUCTION}

Statement of the problem. The Web technologies are being increasingly used in various contexts, and higher education is not an exception. The preparation for life-long learning is especially important for future programmers during a rapid development of the information technology. After graduation from university, most students are satisfied with what has already been achieved, because they are not prepared for self-development. However, the lack of willingness of students to engage in self-education and professional development leads to low competitiveness on the labor market in the future. To solve this problem, we suggest implementing MOOCs in the learning process at university, including the students' independent work while learning a foreign language for professional purposes. It will facilitate further professional development, increase the level of students' knowledge, and expand the range of their interests. The students can communicate with foreign colleagues and see the practical necessity of learning English due to integrating MOOCs in the learning process. 
The diagnostic part of the study has proved the inefficiency of traditional organization of independent work on learning English for professional purposes to prepare students for future careers. The current education system needs some changes because it is expected to prepare future professionals, to form their research skills, and to ensure their continuous lifelong learning. Neil P. Morris (2014) noted, "we must adapt the ways that students are taught and learn in Higher Education as this will impact on their skills, competencies and ability to contribute effectively in a digital workplace and society" [1, p. 401]. The integration of MOOCs in the process of learning English for professional purposes will supplement students' independent learning and help to personalize learning environments.

The successful implementation of MOOCs in students' independent work in English for professional purposes can bring new opportunities to learners, such as enhancing professional skills in programming, increasing English proficiency level, developing critical thinking, decision-making, problem-solving and time management.

Analysis of recent research and publications. The increasing influence of information technology in the educational and scientific fields has contributed to the emergence of the scientific problem connected with the efficiency of using Internet resources and MOOCs for international community that aspires to a high level of professional preparation. We agree with Mathieu d'Aquin (2012) that "the Web is an ideal platform for sharing and exchanging information, and by extension, an obvious enabler in the area of open and distance learning" [2, p. 6]. So researchers have observed great potential for e-learning. In particular, Oleksandr Burov (2016) has identified the following new opportunities offered by e-learning: "flexibility of education programs - a student can choose courses, teachers, time of active work, etc.; individualization of education process - re-allocate time and education resources in dependence on a student's individual psycho-physiological possibilities to make this process more intensive and to give equal opportunities for both common people and people with disabilities" [3]. Jamin Bartolomeo (2015) pointed to fundamental components of MOOCs: "(a) courses are open access, which means that anyone with Internet access may participate for free, and (b) courses are created using online platforms that can accommodate large numbers of users" [4, p.1].

Scientific observations are also related to the problem of integrating MOOCs into the curriculum; adapting them to the thematic modules and different subjects. Marina OrsiniJones (2015) believes that the relevant MOOC is easy to adapt and adopt into an existing curriculum for many subjects. The integration of the MOOC provides the opportunity to explore how learner autonomy can be developed through the engagement with an online course used in conjunction with a face-to-face module. Through their engagement with a MOOC, educators could take a critical stance on the topic of learner autonomy and evaluate the pros and cons of integrating a MOOC into their future curricula [5, p. 7].

The purpose of this research is to study the efficiency of implementing Massive Open Online Courses (MOOCs) in students' independent work while learning a foreign language for professional purposes at university, to define necessary pedagogical conditions of their integration. Through well-matched MOOCs used by an educator learning a foreign language will be professionally oriented. The integration of MOOCs has been used in the form of a flipped classroom in our research to complement traditional independent work in English for professional purposes. A group of scientists opined that "in flipped classrooms, the online component, for example the MOOC, allows students to prepare for in-class discussion by reviewing relevant material beforehand and at their own pace" [6, p. 309].

The purpose has identified the following research objectives:

- to review the outlined problems in scientific literature;

- to outline opportunities for integration of MOOCs in the process of teaching English for professional purposes; 
- to identify the efficiency of using MOOCs for student's professional development;

- $\quad$ to study the efficiency of implementation of MOOCs in students' independent work on a foreign language.

\section{THE THEORETICAL BACKGROUND}

Asha Kanwar (2014) notes that a Massive Open Online Course is a form of distance and online learning. The researcher underlines the speed of propagation of online courses in the world. MOOCs have resulted in major consortia of the top universities on both sides of the Atlantic: Coursera, EdX, Udacity, FutureLearn and many others around the world. Asha Kanwar [7] concludes that there are no subject-related barriers to MOOC offerings.

Neil P. Morris (2014) stated that "well-integrated blended learning approach using pedagogically appropriate tools can enhance student learning and the quality of the student experience" [1, p. 402]. Combining the flipped classroom approach with the integrated use of online learning resources for student collaboration and interactivity, in his opinion, would satisfy many educators and students.

Robin Bartoletti (2016) [8] emphasizes that exploring new pedagogical approaches and technologies in learning experience such as MOOCs offers educators a clear opportunity to reflect on and expand their teaching methods and document effective practices. In particular, Charles Robinson, Hunter Gehlbach and Chris Hulleman (2016) [9] have determined opportunities for predicting success in teaching students at MOOC and other forms of open online learning.

Ashton Anderson and a group of scientists consider that MOOCs have the potential to become a major new mechanism for learning, they list tasks that are offered to students during training such as watching lectures, taking quizzes to test their understanding, working on assignments or exams, and engaging in a forum where they can seek help, offer advice, and have discussions. The course forums provide interesting patterns of interaction, in their opinion, students engage not just with the course material but with each other [10].

While conducting a survey of students who are learning English as a second language and studying a MOOC a group of scientists have determined that it acts as a motivation to learn, such as: "1) to improve their knowledge of the subject area; 2) to acquire English vocabulary in a specialized domain and obtain the course certificate for that specific content in English; 3) to learn about local culture and possibly even build useful contacts; 4) to improve their general English language abilities, as they needed mastery of the language to communicate and obtain the jobs they desired; 5) to improve their ability to manage the regular, unpredictable experiences of daily life; 6) to transcend cultural barriers and access a more valued community" (Uchidiuno, Ogan, Yarzebinski, \& Hammer, 2016) [11]. The researchers argue that the educator should determine the proper motivation in teaching their students in order to obtain the most effective results after passing a MOOC. Another group of scientists describes three forms of teachers who are typically presented at MOOC - the distant "rock star" lecturer, the co-participant or facilitator within a network, and the automated processes that serve as proxy tutor and assessor (Ross, Sinclair, Knox, Bayne, \& Macleod, 2014) [12]. Ian Lee Morris examines student motivation and engagement behaviors in MOOCs through a combination of a literature review and a series of semi-structured interviews with past and present MOOC participants [13, p.4].

Diana Laurillard (2016) [14] noted that MOOC pedagogy fits well with CPD (continuing professional development) that provides some form of updating on current issues and findings, invites participants to discuss and debate the application to their professional contexts, and offers a certificate to put towards their professional development requirements. Colin Milligan and Allison Littlejohn (2014) [15] study professional learning in a MOOC. 
They noted that courses offer a useful approach to professional learning, facilitating the interrelationship between professional practice and learning. Designing tasks encourage the learners to build on existing knowledge and share their experience, motivate and provide learners with evidence that they can use for their own personal development.

However, some researchers have attempted to integrate MOOCs in traditional classroom to support face-to-face learning experiences in blended format (Najafi, Evans, \& Federico, 2014; Israel, 2015; Bartolomeo, 2015). Maria Joseph Israel (2015) [16] indicates two ways of using MOOCs and interactive online technologies in the traditional educational process: 1) learning resources, coupling online and in-class components; 2) in-class instructor and online instructor of a MOOC show two different points of view on the course content.

The reviewed research reports indicate that integrating MOOCs entails curriculum design challenges, because of the persistence of an integrated MOOC over time and the need to find relevant content that enriches existing curriculum [6].

Many researchers argue that students cannot have a meaningful discussion online because thousands of participants and only a few tutors are engaging MOOC at the same time. They propose the following ways to solve this communication issue: numbers of participants need to be limited; use collective knowledge of well-qualified professionals to support other learners (Morris, 2014; Orsini-Jones, Pibworth-Dolinski, Cribb, Brick, \& Gazeley-Eke, 2015 [17]).

\section{METHODS}

The following methods were used for solving these research objectives: analysis and generalization of scientific literature connected with the research problem to determine the state of its scientific elaboration; direct and indirect observation, which has allowed to find out the students' attitude to the process of implementing MOOCs in learning a foreign language for professional purposes; investigation to check pedagogical conditions of effective implementation of MOOCs in the curriculum of students' independent work; quantitative analyses of research results, an efficiency justification of the study.

This study was conducted in the context of the course "English for professional purposes" at SIHE "Kryvyi Rih National University". One hundred twenty-four students from eight groups of the Information Technology Faculty participated in the study. The age range of students was between 19 to 23 years. The groups were randomly divided into the control and experiment groups for research purposes. The control groups learned English according to the current curriculum of students' independent work. The experiment groups signed up for the MOOC on the FutureLearn and met their educator once a week in an hour-long tutorial session. We report on how students in these eight groups were engaged with the learning and assessment components of independent work throughout the several weeks of integration. Also, we compare students' outcomes based on pre-post integration content knowledge tests and assessments.

\section{FINDINGS}

In order to check the efficiency of implementing MOOCs in the process of learning a foreign language for professional purposes, their inclusion in the organization of students' independent work a study has been conducted including teacher's consultations to prepare students for a new kind of educational extracurricular activities, defining forms and methods of controlling the students' independent work, applying learning situations for self-expression through communication with the educator, classmates, presenting the results of studies on the 
MOOC, preparation of creative digital oral presentations. Apart from the classroom consultation there was introduced a remote consultation by e-mail. An evaluation of the efficiency of implementing MOOCs in independent work while learning a foreign language for professional purposes based on checking the results of pre-test and post-test has been conducted. Each stage of the research related to implementing MOOCs in the curriculum of independent work has been carefully considered.

At the first stage of the study, we made a choice of educational online platform and selected courses related to the subject of organizing an independent work on a foreign language course for professional purposes. In the process of research work, it has been clarified that a number of MOOCs have a significant potential for the formation of a professional foreign language competence among students. MOOCs "provide learners with regular, authentic, accessible, and structured opportunities to engage in conversation with other learners about the course materials supported by subject experts" [13, p. 403]. MOOCs materials should be available in the text formats, video and audio. Students recognize and capture the information in line to complete the self-test quizzes at the end.

The independent learning is based on MOOCs category "Online \& Digital", which corresponds to the professional profile of the students' education. The students have the opportunity to chat on-line with foreign specialists of information technology field, discuss educational issues with other participants of the distance course, watch authentic videos and work with additional literature, which is given to each section of the course. Students use MOOCs as additional learning resources and thus, they are introduced to different learning materials related to online learning, web science, cyber security and data analysis (table 1). Our reason for selecting these MOOCs was because a) the course was likely to attract students of Information Technology Faculty; b) MOOCs support a curriculum course; c) learners can master new practical skills; d) duration of the course. Rona Marx (2015) pointed that "any MOOCs introduced as an addition to any pedagogical framework should be subject related and should be directly relevant to the discipline of EFL teaching. It should be regarded as asynchronous learning, in which student autonomy should be encouraged" [18, p. 139].

Table 1

MOOCs integrated into the curriculum of student's independent work.

\begin{tabular}{|c|c|c|c|}
\hline $\begin{array}{c}\text { Year } \\
\text { of } \\
\text { study }\end{array}$ & $\begin{array}{c}\text { Time period } \\
\text { of study }\end{array}$ & Course name & Link \\
\hline II & October 2016 & $\begin{array}{c}\text { Get Started with Online } \\
\text { Learning }\end{array}$ & $\begin{array}{c}\text { https://ww.futurelearn.com/courses/ } \\
\text { online-learning }\end{array}$ \\
\hline III & $\begin{array}{c}\text { November } \\
2016\end{array}$ & $\begin{array}{c}\text { Web Science: How the Web } \\
\text { Is Changing the World }\end{array}$ & $\begin{array}{c}\text { https://www.futurelearn.com/courses/ } \\
\text { web-science }\end{array}$ \\
\hline IV & October 2016 & $\begin{array}{c}\text { Introduction to Cyber } \\
\text { Security }\end{array}$ & $\begin{array}{c}\text { https://www.futurelearn.com/courses/ } \\
\text { introduction-to-cyber-security }\end{array}$ \\
\hline V & October 2016 & $\begin{array}{c}\text { Learn to Code for Data } \\
\text { Analysis }\end{array}$ & $\begin{array}{c}\text { https:/www.futurelearn.com/courses/ } \\
\text { learn-to-code }\end{array}$ \\
\hline
\end{tabular}

The second stage of the study ensured the formation of positive motivation and elementary knowledge of students about training at MOOCs and was implemented during the extracurricular activities and consultations with the aim of preparing for the implementation of independent work curriculum on the subject "Foreign language for professional purposes". Integration of the courses from the education platform FutureLearn ensured the learning and assimilation by the students of the necessary educational information that would contribute to their professional formation. Mary-Ann Fife (2016) mentioned that "FurureLearn emphasizes the social aspect of learning in a MOOC by encouraging course designers to ask prompting questions after some of the videos and providing a space for discussion after every step" [19, p. 117]. 
Students received the emails with a request to sign up for a MOOC on the FutureLearn [20]. An educator asked students to follow the online materials and complete all assignments. They provided screenshots of their works and submitted them to the class.

The third stage of the study is based on the integration of MOOCs into the learning process of a foreign language for professional purposes. The formation of system knowledge and skills of future programmers is started with the purpose of preparing a competitive specialist who is ready for life-long learning and self-improvement. The students create their own profile and via it carry out the social connections with other learners while studying. Mathieu d'Aquin (2012) notes in his work, that such social connections support learning activities and bring benefit from sharing their learning experience [2].

At the next stage, the students systematized and deepened their knowledge and skills on the topics of the completed MOOCs, enriched the practical experience by using a foreign language in the process of studying the material related to their major. The control over the assimilation of acquired knowledge during students' independent learning of the material was carried out through multimedia presentations which presented the results of passing the distance course. Preparation of the presentation included: construction of a clear algorithm of the report, deliberate artistic design and technical support of the material. Requirements for presentations include: 1) timeliness of implementation; 2) the report is informative, clear, logical, and it reflects the main content of the work; 3) availability of the illustrative material. Training in MOOCs facilitates the development of such types of language activity as listening, reading and writing. Discussion and presentations according to the results of passing the course provide students with the opportunity to practice speaking. The educator should encourage the creativity of responses such as offering students the opportunity to present their work in different ways, including video, written and oral presentation.

Student engagement and student outcomes during the duration of their MOOC participation were of importance to this research. At the final stage of the work with the goal to interpret the results of the research we made a comparison between the scores of students' pre-test (figure 2) and post-test (figure 3). The tests covered materials gained from students' independent work. Based on quantitative and qualitative comparative analysis of results, the research has identified the efficiency of integrating MOOCs into the curriculum of independent work while learning a foreign language by students majoring in information technology.

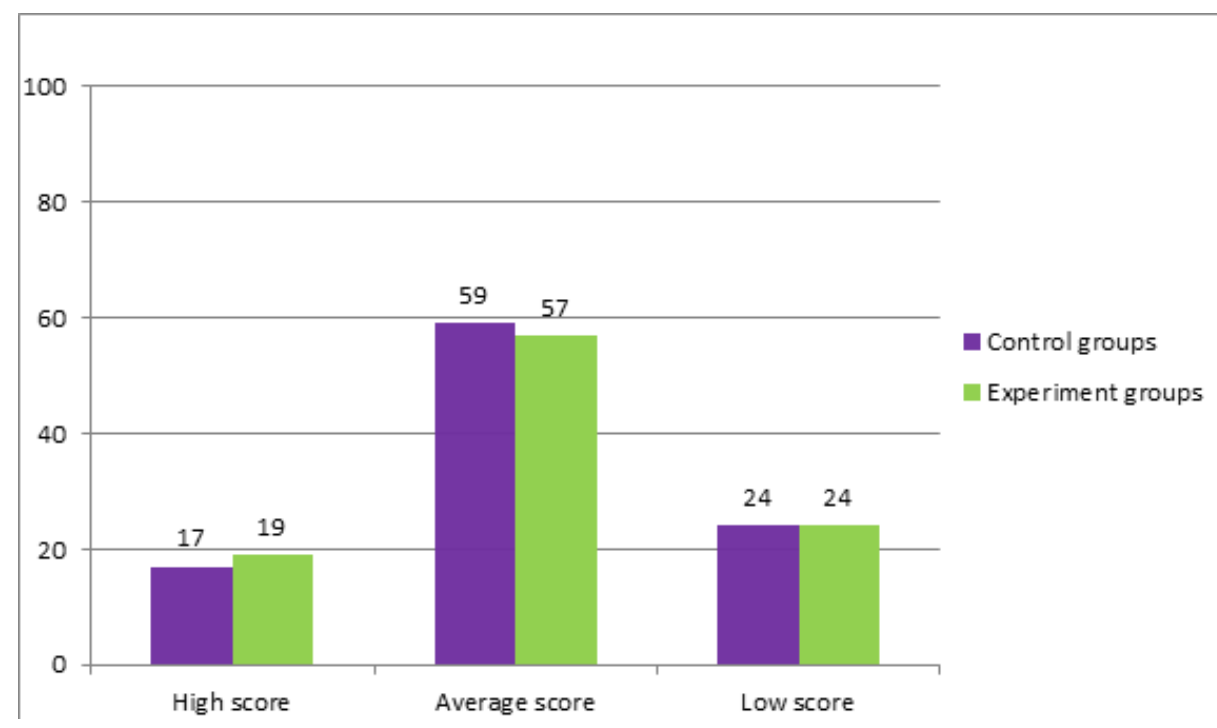

Figure 1. Results of students' pre-test 
As illustrated in Figure 1, the pre-test did not show a significant difference between the groups on their scores (experiment groups (EGs) high score $=19 \%$, control groups (CGs) high score $=17 \%$; EGs average score $=57 \%$, CGs average score $=59 \%$; EGs and CGs have the same low score $=24 \%$ ).

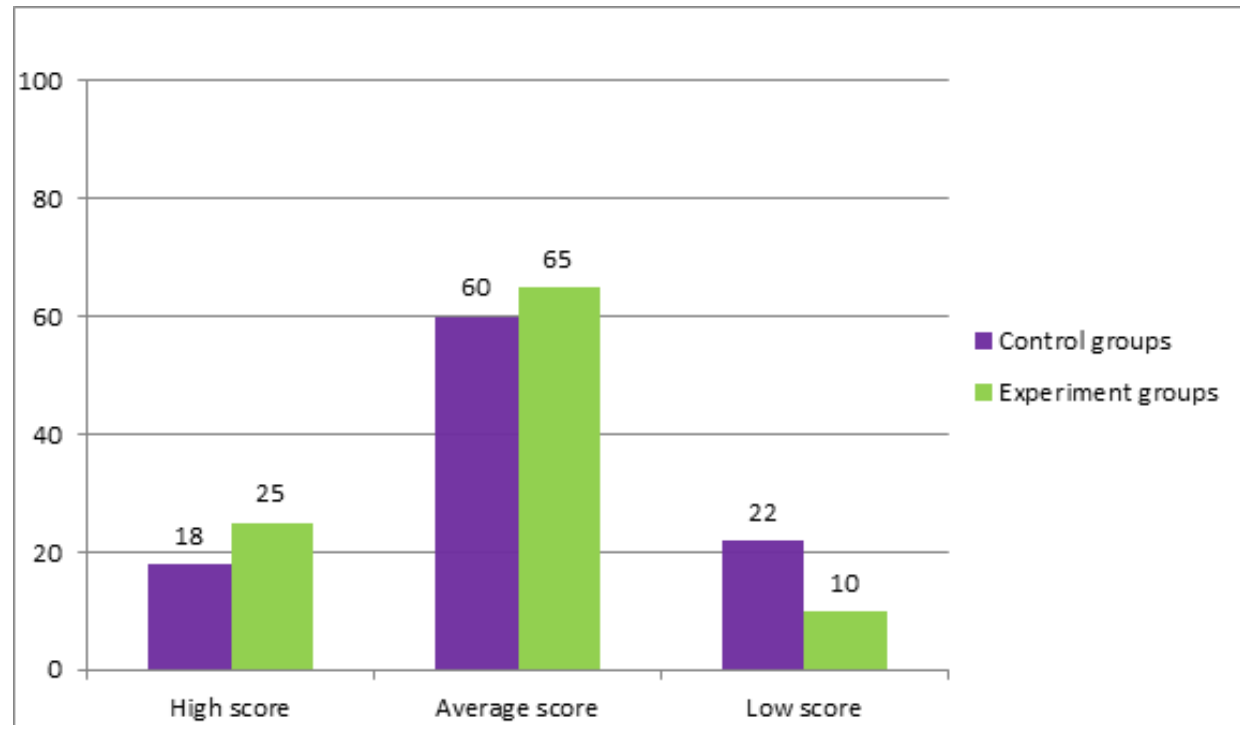

Figure 2. Results of students' post-test

As reflected in Figure 2, control groups scored lower in the post-test (high score $=18 \%$; average score $=60 \%$; low score $=22 \%$ ) compared to experiment groups (high score $=25 \%$; average score $=65 \%$; low score $=10 \%$ ). Test results showed that students who engaged in MOOC, participated in the online discussion forum, watched online lecture videos in addition to their face to face classroom scored higher than those who only relied on face to face classroom learning and prepared current curriculum assignments. Experiment groups scores reflected their level of persistence and engagement with learning the integrated MOOC.

The study did not reveal a considerable difference between scores of pre-test and posttest for control groups. Students' scores of experiment groups in content knowledge pre-test, written at the start of MOOCs integration, and post-test, written after the integration, showed an increase in their knowledge of English for professional purposes (6\% increase in high score, $8 \%$ increase in average score, low score declined by $14 \%$ ). Thus, the formation of a high level of knowledge was found in $25 \%$ of students, and the average level - in $65 \%$ of students, which demonstrated the students' ability to study MOOCs, work independently, gain new knowledge and engage self-development.

Finally, we investigated the efficiency of MOOCs implementation while observing student's digital oral presentations. The representatives from each group by turns were performing presentations about their learning. Students of the experiment groups showed willingness to join the training at MOOCs for learning the foreign language for professional purposes in order to increase the level of skills and knowledge in future. The experiment groups gave more correct answers than the control groups. Thus, the study also found no adverse effect of the integrated MOOCs on students' learning. Despite positive results and all benefits of MOOCs (figure 3), the students of experiment groups expressed disappointment as they did not receive direct feedback, their questions were not answered by the online instructors in MOOCs. Students found it easier to interact with the educator face-to-face in classrooms where they could get their questions answered. 


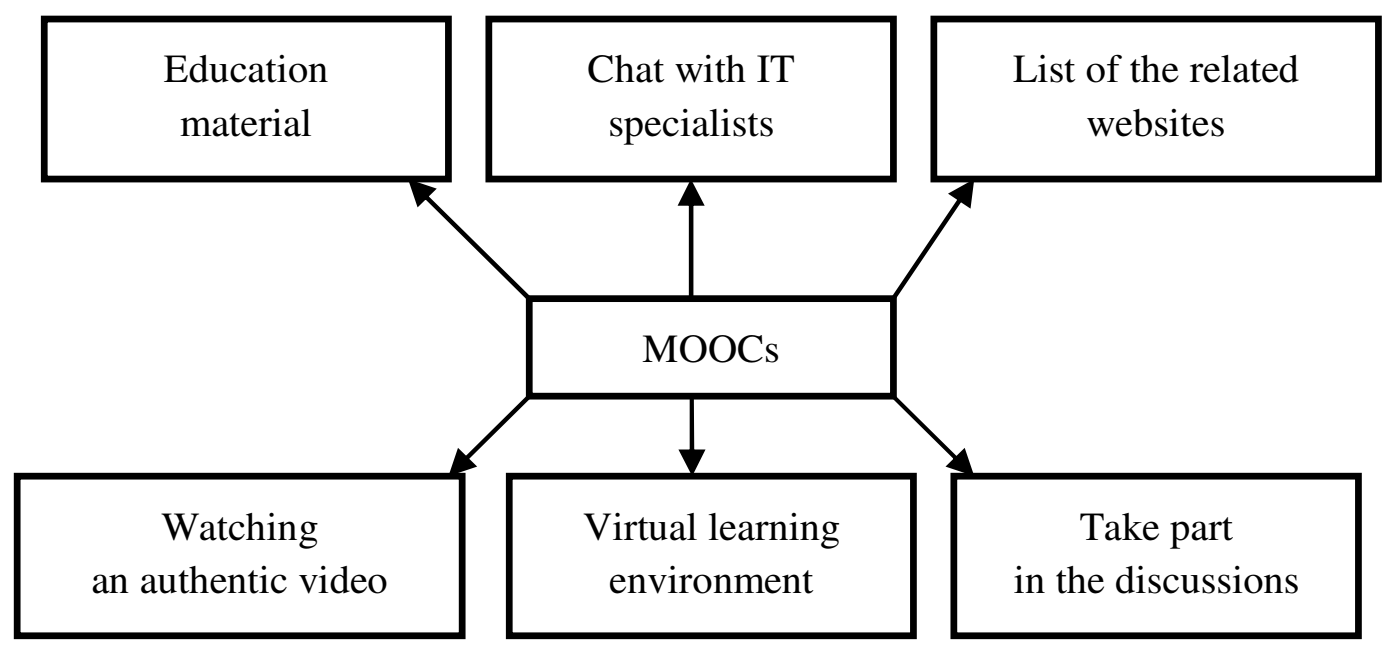

Fig. 3. The benefits of MOOCs

Thus, successful integration of MOOCs depends on a number of factors:

- MOOCs should be appropriate for students' needs and interests.

- The role of the educator supporting independent learning.

- A strong relationship between the educator and the student.

- Skills that each student has to acquire.

- Students' ability to work on their own.

Research shows that many students are interested in MOOCs, and they want to choose it for supporting lifelong learning and for professional development. Rona Marx (2015) emphasizes that "student autonomy and appropriate digital literacy skills are key to the MOOC's successful application to teaching practice for individual students" [18, p. 136]. Students' motivation plays important role in completing in-class and online activities. Learners get new social experience and explore online education due to integrating MOOCs into an existing curriculum.

\section{CONCLUSIONS AND PROSPECTS FOR FURTHER RESEARCH}

MOOCs training allows students to demonstrate their experience in studying, to realize their own interest, to create a professional language base, to demonstrate proficiency in a foreign language, to create conditions for active development and independent thinking. This study shows the efficiency of MOOCs as additional resources in studying English for professional purposes. The research confirms that educator's presence may positively affect students learning the integrated content of MOOCs.

Learning a foreign language will be not only professionally-oriented but also contribute to the practical training of students majoring in this field due to the involvement of MOOCs into the curriculum of students' independent work. It will involve the use of information and communication technology of distance learning in the traditional educational process.

This research does not cover all aspects of the outlined problems. Further scientific research is seen in the study on the implementation of MOOCs in postgraduate education, self-education and in training students of different specialties while learning a foreign language. 


\section{REFERENCES}

[1] Neil P. Morris, "How digital technologies, blended learning and MOOCs will impact the future of higher education", Lisbon, Portugal, pp. 401-404 July 15-19, 2014. [Online]. Available: http://files.eric.ed.gov/fulltext/ED557272.pdf. (in English)

[2] M.d'Aquin, "Linked Data for Open and Distance Learning", 2012. [Online]. Available: http://oasis.col.org/handle/11599/219. (in English)

[3] O. Burov, "Life-Long Learning: Individual Abilities versus Environment and Means", 2016. [Online]. Available: http://ceur-ws.org/Vol-1614/paper_86.pdf. (in English)

[4] J. Bartolomeo, "The Discourse Among Community College Faculty Regarding the Integration of Massive Open Online Courses", 2015. [Online]. Available: http://pqdtopen.proquest.com/pubnum/3687817.html (in English)

[5] M. Orsini-Jones, "Innovative pedagogies series: Integrating a MOOC into the MA in English Language Teaching at Coventry University", 2015. [Online]. Available: https://www.heacademy.ac.uk/.../marina_orsini_jones_final_1.pdf. (in English)

[6] H. Najafi, R. Evans, and C. Federico, "MOOC Integration into Secondary School Courses. International Review of Research in Open and Distance Learning", pp. 306-322, 2014. [Online]. Available: http://files.eric.ed.gov/fulltext/EJ1045969.pdf. (in English)

[7] A. Kanwar, "Developments in distance and online learning", 2014. [Online]. Available: http://oasis.col.org/handle/11599/1031. (in English)

[8] R. Bartoletti, "Learning through Design: MOOC Development as a Method for Exploring Teaching Methods. Current Issues in Emerging eLearning", Vol. 3, Iss. 1, 2016. [Online]. Available: http://scholarworks.umb.edu/cgi/viewcontent.cgi?article=1025\&context=ciee. (in English)

[9] C. Robinson, H. Gehlbach, and C. Hulleman, "Forecasting student achievement in MOOCs with natural language processing", 2016. [Online]. Available: https://www.researchgate.net/publication/301591270_Forecasting_student_achievement_in_MOOCs_wit h_natural_language_processing. (in English)

[10] A. Anderson, D. Huttenlocher, J. Kleinberg, and J. Leskovec, "Engaging with Massive Online Courses", 2014. [Online]. Available: https://www.cs.cornell.edu /home/kleinber/www14-courses.pdf. (in English)

[11] J. Uchidiuno, A. Ogan, E. Yarzebinski, and J. Hammer, "Understanding ESL Students' Motivations to Increase MOOC Accessibility", $2016 . \quad$ [Online]. Available: https://www.researchgate.net/publication/301322209_Understanding_ESL_Students' _Motivations_to_Increase_MOOC_Accessibility. (in English)

[12] J. Ross, C. Sinclair, J. Knox, S. Bayne, and H. Macleod, "Teacher Experiences and Academic Identity: The Missing Components of MOOC Pedagogy", 2014. [Online]. Available: jolt.merlot.org/vol10no1/ross_0314.pdf. (in English)

[13] Ian L. Morris, "An Exploratory Analysis of Elements of Motivation and Engagement in Massive Online Open Courses (MOOCs) ", 2014. [Online]. Available: http://escholarship.org/uc/i"tem/3701p4xz. (in English)

[14] D. Laurillard, How should professors adapt to the changing digital education environment? " Pp. 3-16, 2016. [Online]. Available: http://portlandpresspublishing.com/content/wenner-gren-international-seriesvolume-88. (in English)

[15] C. Milligan, and A. Littlejohn, "Supporting Professional Learning in a Massive Open Online Course", pp. 197-213, 2014. [Online]. Available: http://files.eric.ed.gov/fulltext/EJ1045992.pdf. (in English)

[16] Maria J. Israel, "Effectiveness of Integrating MOOCs in Traditional Classrooms for Undergraduate Students", pp. 102-118, 2015. [Online]. Available: http://files.eric.ed.gov/fulltext/EJ1077803.pdf. (in English)

[17] M. Orsini-Jones, L. Pibworth-Dolinski, M. Cribb, B. Brick, and Z. Gazeley-Eke, "Learning about language learning on a MOOC: how Massive, Open, Online and "Course"? Pp. 450-457, 2015. [Online]. Available: http://files.eric.ed.gov/fulltext/ED564239.pdf. (in English)

[18] R. Marx, "Investigating the effectiveness of using MOOCs and webinars in enhancing teaching and learning in a Teaching English as a Foreign Language (TEFLA) Course in a Distance Education Environment: A case study of a Short Learning Programme", 2015. [Online]. Available: http://hdl.handle.net/10500/21044. (in English)

[19] Mary-Ann Fife, "The influence of video lectures on student engagement in the University of Cape Town's First Massive Open Online Course", 2016. [Online]. Available: http://hdl.handle.net/11427/22800. (in English)

[20] British Council. "Online courses", 2016. [Online]. Available: https://www.futurelearn.com/courses. (in English) 


\title{
ЕФЕКТИВНІСТЬ ВПРОВАДЖЕННЯ МВОК В ПРОЦЕС НАВЧАННЯ АНГЛІЙСЬКОЇ МОВИ ЗА ПРОФЕСІЙНИМ СПРЯМУВАННЯМ
}

\author{
Шалацька Ганна Миколаївна \\ кандидат філологічних наук, доцент кафедри іноземних мов \\ ДВНЗ «Криворізький національний університет», м. Кривий Ріг, Україна \\ ORCID ID 0000-0002-1231-8847 \\ shalatska@i.ua
}

\begin{abstract}
Анотація. У статті розглянуто спосіб інтеграції Масових відкритих он-лайн курсів (МВОК) у навчальний процес і визначено їх роль у мотивації студентів до вивчення іноземної мови за професійним спрямуванням. Метою дослідження є вивчення ефективності впровадження МВОК у план самостійної роботи студентів під час вивчення іноземної мови за професійним спрямуванням в університеті. Враховуючи зростаючу потребу у високо освічених спеціалістах у всьому світі, дослідження використання МВОК у навчальному процесі набуває своєї актуальності. Отже, залучення студентів факультету інформаційних технологій до вивчення інтегрованого курсу може підвищити їх навички i знання у програмуванні. Інтеграція МВОК у процес навчання англійській мові в професійних цілях допоможе персоналізувати освітне середовище i підготувати майбутніх фахівців. Дослідження показує, що успішна реалізація МВОК може принести нові можливості тому, хто навчається, такі як підвищення рівня володіння англійською мовою, розвиток критичного мислення, ухвалення рішень, розв'язання проблем і управління часом. Ми розглядаємо наукову проблему, пов'язану з ефективністю використання інтернет-ресурсів і МВОК, способів використання інтерактивних он-лайн-технологій у традиційному освітньому процесі, потенціал i виявлення нових можливостей, запропонованих електронним навчанням. Наші спостереження також пов'язані 3 проблемою інтеграції МВОК у навчальну програму, адаптуючи їх до тематичних модулів i різних тем. Дослідження показує, що успішна інтеграція МВОК в процес навчання іноземній мові в професійних цілях залежить від низки чинників. Кожен етап нашого дослідження ретельно розглядається в статті. Це дослідження показує ефективність МВОК як додаткових ресурсів у вивченні англійської мови в професійних цілях і описує використання інформаційних $\mathrm{i}$ комунікаційних технологій дистанційного навчання у традиційному навчальному процесі. У статті описано можливість використання переваг МВОК у навчальному процесі університетами, які вважають ефективним впровадження МВОК у процес викладання англійської мови за професійним спрямуванням.
\end{abstract}

Ключові слова: МВОК; мотивація; упровадження; самостійна робота; «перевернуте навчання»; безперервне навчання.

\section{ЭФФЕКТИВНОСТЬ ВНЕДРЕНИЯ МООК В ПРОЦЕСС ОБУЧЕНИЯ АНГЛИЙСКОМУ ЯЗЫКУ СООТВЕТСТВЕННО ПРОФЕССИОНАЛЬНОЙ НАПРАВЛЕННОСТИ}

\author{
Шалацкая Анна Николаевна \\ кандидат филологических наук, доцент кафедры иностранных языков \\ ГВУЗ «Криворожский национальный университет», г. Кривой Рог, Украина \\ ORCID ID 0000-0002-1231-8847 \\ shalatska@i.ua
}

\begin{abstract}
Аннотация. В статье рассмотрен способ интеграции Массовых открытых онлайн курсов (МООК) в учебный процесс и определена их роль в мотивации студентов к изучению иностранного языка соответственно профессиональной направленности. Целью исследования является изучение эффективности внедрения МООК в план самостоятельной работы студентов во время изучения иностранного языка в университете. Учитывая растущую потребность в высокообразованных специалистах во всем мире, исследование использования МООК в учебном процессе приобретает свою актуальность. Следовательно, привлечение студентов факультета информационных технологий к изучению
\end{abstract}


интегрированного курса может повысить их навыки и знания в программировании. Интеграция МООК в процесс обучения английскому языку в профессиональных целях поможет персонализировать учебную среду и подготовить будущих специалистов. Исследование показывает, что успешная реализация МООК может принести новые возможности учащимся, такие как повышение уровня владения английским языком, развитие критического мышления, принятие решений, решение проблем и управление временем. Мы рассматриваем научную проблему, связанную с эффективностью использования интернет-ресурсов и МООК, способы использования интерактивных онлайнтехнологий в традиционном образовательном процессе, потенциал и выявление новых возможностей, предлагаемых электронным обучением. Наши наблюдения также связаны с проблемой интеграции МООК в учебную программу, адаптируя их к тематическим модулям и различным темам. Исследование показывает, что успешная интеграция МООК в процесс обучения иностранному языку в профессиональных целях зависит от ряда факторов. Каждый этап нашего исследования тщательно рассматривается в статье. Это исследование показывает эффективность МООК как дополнительных ресурсов при изучении английского языка в профессиональных целях и описывает использование информационных и коммуникационных технологий дистанционного обучения в традиционном учебном процессе. В статье описана возможность использования преимуществ МООК в учебном процессе университетами, которые считают эффективным внедрение МООК в преподавании английского языка соответственно профессиональной направленности.

Ключевые слова: МООК; мотивация; внедрение; самостоятельная работа; «перевернутое обучение»; «обучение на протяжении жизни».

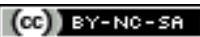

This work is licensed under Creative Commons Attribution-NonCommercial-ShareAlike 4.0 International License. 